\title{
MODEL ARSITEKTUR POHON ARBORETUM UNIVERSITAS LANCANG KUNING SEBAGAI PENUNJANG PEMBELAJARAN
}

\author{
Hadinoto, Eni Suhesti \\ Staff Pengajar Fakultas Kehutanan Universitas Lancang Kuning \\ JIn. Yos Sudarso Km. 8 Rumbai Pekanbaru Riau \\ Email : hadinoto@unilak.ac.id dan suhestieni@unilak.ac.id
}

\begin{abstract}
Arboretum is an example of forest which is a collection of trees which is a form of conservation of human-made germplasm. Arboretum with various vegetation containing scientific values can be used as an open laboratory for student education and research facilities. The pattern of branching plants will form a form of plant architecture. The branching architecture is a morphological representation of a particular phase of a series of tree growth series, real and observable at all times. This research was conducted by conducting a survey (survey) and direct observation of the model of bamboo branching architecture in plants located in the research location. Identification of tree architecture model using book by $F$. Halle \& R.A.A.Oldeman, namely: An Essay On The Architecture and Dynamics of Growth of Tropical Trees. Each tree is observed and photographed, as research documentation. Analysis conducted in this research is descriptive analysis to the type and shape of architectural architecture of Arboretum University of Lancang Kuning. Based on the results of research that has been done, can be drawn conclusion as follows: obtained 10 shapes / models of tree architecture of 41 species of trees (diamater $\geq 20 \mathrm{~cm}$ ). Architectural tree form / model in Arboretum ie Aubreville, Champagnat, Koriba, Leeuwenberg, Massart, Prevost, Rauh, Roux, Scarrone and Troll. The results of such research will contribute to the concept of development of the learning process. The results of this study can be used by students in the Forest Hydrology practice, Watershed Management, Urban Forest Science, Dendrology and Climatology.
\end{abstract}

Keywords: arboretum; architectural model; tree

\section{PENDAHULUAN}

\section{Latar Belakang}

Arboretum adalah suatu contoh

hutan yang merupakan kumpulan pepohonan yang merupakan bentuk konservasi plasma nutfah buatan manusia. Arboretum Fakultas Kehutanan telah ada seiring berdirinya
Fakultas Kehutanan pada tahun 1998. Pengelolaan kawasan arboretum bertujuan untuk meningkatkan peran kawasan tersebut sebagai pelindung penyangga sumberdaya hutan dan air daerah sekitarnya. Selain itu, kawasan tersebut juga dapat dijadikan sebagai sarana rekreasi, pendidikan dan 
penelitian. Di dalam arboretum terdapat keanekaragaman hayati tumbuhan dan satwaliar yang hidup alami. Oleh karena itu, arboretum ini berpotensi untuk dikembangkan sebagai salah satu pusat laboratorium alam bagi segenap civitas akademika untuk kegiatan praktikum dan penelitian.

Arboretum dengan aneka vegetasi yang mengandung nilai-nilai ilmiah dapat dijadikan laboratorium terbuka untuk sarana pendidikan dan penelitian mahasiswa, tertutama dalam mempelajari pola percabangan pohon pada beberapa matakuliah antara lain : Ilmu Hutan Kota, Dendrologi, Biologi dan lainnya. Percabangan pohon merupakan diferensiasi morfologi pada sumbu vegetatif dan arsitektur khusus untuk klasifikasi dan interpretasi bentuk tumbuhan. Batang suatu tumbuhan ada yang bercabang ada yang tidak. Pola percabangan batang tumbuhan dibedakan atas tiga macam, yaitu pola percabangan monopodium, pola percabangan simpodium, dan pola percabangan menggarpu atau dikotom (Tjitrosoepomo, 2007).

Pola percabangan tumbuhan akan membentuk bentuk arsitektur tumbuhan. Arsitektur percabangan merupakan gambaran morfologi pada suatu fase tertentu dari suatu rangkaian seri pertumbuhan pohon, nyata dan dapat diamati setiap waktu. Konsep arsitektur menunjukkan sifatnya yang dinamis Karena tumbuhan terus berkembang menurut waktu dan ruang. Bentuk arsitektur terlihat pada saat tumbuhan yang masih muda dan tumbuh dengan baik. Bentuk arsitektur diterapkan untuk tumbuhan berhabitus pohon sebagai gambaran dari salah satu fase dalam rangkaian pertumbuhan pohon tersebut. Setiap jenis pohon memiliki ciri yang khas dalam rangkaian proses pertumbuhannya yang diwariskan secara genetik pada keturunannya. Oleh karena sifatnya yang konsisten maka bentuk arsitektur pada setiap jenis pohon dapat dijadikan data tambahan dalam membedakannya dengan jenis pohon lain.

Dalam mempelajari morfologi tumbuhan beberapa hal yang dikaji antara lain bentuk dan susunan tubuh bagian luar tumbuhan, yaitu akar, batang, daun, bunga, dan biji. Khusus pada batang, salah satu bagian yang dipelajari adalah pola percabangan yang selanjutnya akan membentuk arsitektur pohon. Beberapa contoh kajian bentuk arsitektur pohon dengan beberapa mata kuliah antara lain hubungannya dengan 
aliran batang, air lolosan tajuk, keindahan tajuk hutan kota, keanekaragaman jenis satwa liar, media pembelajaran dan lainnya. Dengan demikian hasil penelitian ini dapat dijadikan sebagai media dalam mempelajari beberapa matakuliah. Berdasar pada hal tersebut di atas maka dilakukan penelitian ini dengan topik "Identifikasi bentuk arsitektur pohon di Arboretum Universitas Lancang Kuning sebagai Penunjang Praktikum beberapa Mata Kuliah di Fakultas Kehutanan”.

\section{Tujuan Penelitian}

Tujuan penelitian ini adalah untuk mengidentifikasi bentuk arsitektur pohon yang terdapat di Arboretum Universitas Lancang Kuning,.

\section{Manfaat Penelitian}

Penelitian ini

selanjutnya diharapkan dapat dimanfaatkan sebagai media pembelajaran beberapa mata kuliah antara lain : Ilmu Hutan Kota, Biologi, Hidrologi Hutan dan Pengelolaan Daerah Aliran Sungai, Klimatologi Hutan dan Dendrologi dan lainnya
METODE PENELITIAN

Tempat dan Waktu

Penelitian ini dilakukan di Arboretum Universitas Lancang Kuning Pekanbaru. Waktu penelitian mulai Oktober 2017 - Januari 2018.

\section{Alat dan Bahan}

Alat yang digunakan dalam penelitian ini antara lain : alat tulis, kamera, meteran, phi band, papan alas tulis, buku panduan pengenalan pohon. Sedangkan bahan yang digunakan tally sheet dan pohon sebagai objek

\section{Jenis Data}

\section{Data Primer}

Data-data yang diambil secara langsung di lapangan terdiri atas : jenis pohon (diameter $\geq 20 \mathrm{~cm}$ ) dan bentuk arsitektur pohon.

\section{Data Sekunder}

Data sekunder dikumpulkan melalui studi literatur. Data sekunder merupakan data pendukung yang sangat penting dan dikumpulkan dari berbagai sumber antara lain buku teks, hasil-hasil penelitian, jumal penelitian, internet dan sumber lainnya. 


\section{Metode Pengumpulan Data}

Penelitian ini dilakukan dengan melakukan jelajah (survey) dan pengamatan secara langsung terhadap model arsitektur percabangan batang pada tumbuhan yang terdapat di lokasi penelitian. Identifikasi model arsitektur pohon menggunakan buku karangan $\mathrm{F}$. Halle \& R.A.A.Oldeman, yaitu: An Essay On The Architecture and Dynamics of Growth of Tropical Trees. Setiap pohon diamati dan difoto, sebagai dokumentasi penelitian.

\section{Analisis Data}

Analisis yang dilakukan dalam penelitian ini adalah analisis deskriptif terhadap jenis dan bentuk arsitektur pohon penyusun Arboretum Universitas Lancang Kuning.

\section{HASIL DAN PEMBAHASAN \\ Arsitektur Pohon Arboretum}

Berdasar pada hasil penelitian di Arboretum Universitas Lancang Kuning (Arboretum UNILAK), didapatkan 10 bentuk/model arsitektur pohon dari 41 jenis pohon (diamater $\geq 20 \mathrm{~cm}$ ). Bentuk/model arsitektur pohon di Arboretum yaitu Aubreville, Champagnat, Koriba, Leeuwenberg, Massart, Prevost, Rauh, Roux, Scarrone dan Troll (Tabel 1) dan persentase jumlah jenis pohon dengan model arsitekturnya (Gambar 3)

Tabel 1. Bentuk arsitektur pohon di Arboretum UNILAK

\begin{tabular}{|c|c|c|c|c|c|c|}
\hline No & $\begin{array}{c}\text { Bentuk/Model } \\
\text { Arsitektur } \\
\text { Pohon }\end{array}$ & No & Nama ilmiah & No & Nama Daerah & Famili \\
\hline \multirow{4}{*}{1} & \multirow{4}{*}{ AUBREVILLE } & 1 & Elaeocarpus glaber & 1 & Bangkinang & Elaeocarpaceae \\
\hline & & 2 & $\begin{array}{l}\text { Endospermum } \\
\text { duodenum }\end{array}$ & 2 & $\begin{array}{l}\text { Sendok- } \\
\text { Sendok } \\
\end{array}$ & Euphorbiaceae \\
\hline & & 3 & Macaranga sp & 3 & Mahang & Euphorbiaceae \\
\hline & & 4 & Palaquium hexandrum & 4 & Balam & Sapotaceae \\
\hline 2 & CHAMPAGNAT & 1 & Pleomele lincarifolia & 5 & Tawota & Ruscaceae \\
\hline 3 & KORIBA & 1 & Pometia pinnata & 6 & Matoa & Sapindaceae \\
\hline 4 & LEEUWENBERG & 1 & $\begin{array}{l}\text { Calophyllum } \\
\text { inophyllum }\end{array}$ & 7 & Bintangur & Clusiaceae \\
\hline 5 & MASSART & 1 & Horsfielda grandis & 8 & Mendarahan & Myristicaceae \\
\hline \multirow[b]{2}{*}{6} & \multirow[b]{2}{*}{ PREVOST } & 1 & Alstonia scholaris & 9 & Pulai & Apocynaceae \\
\hline & & 2 & $\begin{array}{l}\text { Stemonurus } \\
\text { scorpiodes }\end{array}$ & 10 & Pasir-Pasir & Icacinaceae \\
\hline \multirow{4}{*}{7} & \multirow{4}{*}{ RAUH } & 1 & Gluta renghas & 11 & Rengas & Anacardiaceae \\
\hline & & 2 & Santiria laevigata & 12 & Lalan & Burseraceae \\
\hline & & 3 & Hevea brasiliensis & 13 & Karet & Euphorbiaceae \\
\hline & & 4 & $\begin{array}{l}\text { Artocarpus elasticus } \\
\text { Rein.W. }\end{array}$ & 14 & Terap & Moraceae \\
\hline
\end{tabular}




\begin{tabular}{|c|c|c|c|c|c|c|}
\hline \multirow[t]{7}{*}{ No } & $\begin{array}{l}\text { Bentuk/Model } \\
\text { Arsitektur }\end{array}$ & No & Nama ilmiah & No & Nama Daerah & Famili \\
\hline & & 5 & Artocarpus rigidus $B L$. & 15 & Tempunik & Moraceae \\
\hline & & 6 & Sloetida elongata Kds. & 16 & Trempinis & Moraceae \\
\hline & & 7 & Artocarpus nitidus & 17 & Teampinai & Moraceae \\
\hline & & 8 & Parartocarpus trianda & 18 & Tenggayun & Moraceae \\
\hline & & 9 & Ficus benjamina & 19 & Beringin & Moraceae \\
\hline & & 10 & Styrax benzoin & 20 & Kemenyan & Styracaceae \\
\hline \multirow{6}{*}{8} & \multirow{6}{*}{ ROUX } & 1 & Xylopia ferruginga & 21 & Jangkang & Annonaceae \\
\hline & & 2 & Polyalthia hypoleuca & 22 & Mempisang & Annonaceae \\
\hline & & 3 & Shorea balangeran & 23 & $\begin{array}{l}\text { Meranti } \\
\text { Balangeran } \\
\end{array}$ & Dipterocarpaceae \\
\hline & & 4 & Shorea macrophylla & 24 & $\begin{array}{l}\text { Meranti Daun } \\
\text { Besar }\end{array}$ & Dipterocarpaceae \\
\hline & & 5 & Shorea macrantha & 25 & Meranti Rawa & Dipterocarpaceae \\
\hline & & 6 & Aquilaria malaccensis & 26 & Gaharu & Thymelaceae \\
\hline \multirow{4}{*}{9} & \multirow{4}{*}{ SCARRONE } & 1 & $\begin{array}{l}\text { Campnosperma } \\
\text { auriculatum Hoo.f }\end{array}$ & 27 & Terentang & Anacardiaceae \\
\hline & & 2 & Dillenia grandifolia & 28 & Simpur & Dilleniaceae \\
\hline & & 3 & Dialium indum & 29 & Keranji & Fabaceae \\
\hline & & 4 & Nephelium mutabile & 30 & $\begin{array}{l}\text { Rambutan } \\
\text { Hutan }\end{array}$ & Sapindaceae \\
\hline \multirow{11}{*}{10} & \multirow{11}{*}{ TROLL } & 1 & Pithecellobium lobatum & 31 & Jengkol & Bignoniaceae \\
\hline & & 2 & Garcinia parvifolia & 32 & Kandis & Clusiaceae \\
\hline & & 3 & $\begin{array}{l}\text { Pterocarpus } \\
\text { macrocarpus }\end{array}$ & 33 & Dalok & Fabaceae \\
\hline & & 4 & Falcataria moluccana & 34 & Sengon & Fabaceae \\
\hline & & 5 & Canavalia gladiata & 35 & $\begin{array}{l}\text { Kacang } \\
\text { Pedang }\end{array}$ & Fabaceae \\
\hline & & 6 & Ixonanthes reticulate & 36 & Pagar-Pagar & Linaceae \\
\hline & & 7 & Artocarpus sp & 37 & Nangka Hutan & Moraceae \\
\hline & & 8 & Syzygium sp & 38 & Jambu-Jambu & Myrtaceae \\
\hline & & 9 & Tritaniopsis whiteana & 39 & Pelawan Putih & Myrtaceae \\
\hline & & 10 & $\begin{array}{l}\text { Ochanostachys } \\
\text { amentacea }\end{array}$ & 40 & Petatal & Olacaceae \\
\hline & & 11 & Vitex pinnata & 41 & Laban & Verbenaceae \\
\hline
\end{tabular}

Sumber : Data olahan (2018)

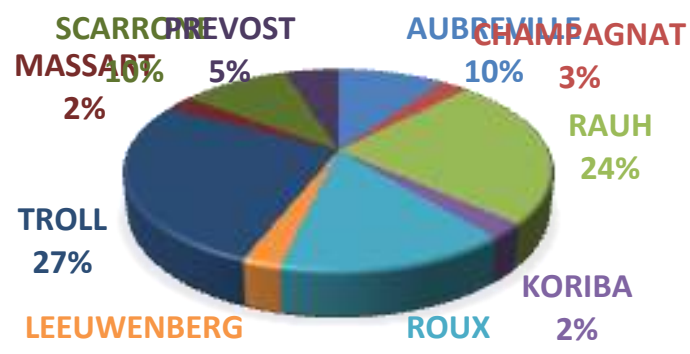

Gambar 3. Persentase jumlah jenis pohon dengan model arsitekturnya. 
Dari Tabel 1 dan Gambar 3 di atas menunjukkan bahwa terdapat beragam model arsitektur pohon di Arboretum UNILAK. Model Troll mendominasi bentuk arsitektur pohon di Arboretum UNILAK yaitu 11 jenis pohon dan diikuti model Rauh dengan 10 jenis pohon. Hal ini menunjukkan bahwa 2 model ini merupakan bentuk arsitektur yang umum ditemukan di hutan Indonesia termasuk Arboretum UNILAK. Sementara model arsitektur pohon lainnya persentasenya kecil. Meskipun demikian Arboretum UNILAK memiliki jumlah cukup untuk model arsitektur pohon yang dapat digunakan untuk berbagai keperluan kegiatan proses belajar mengajar di Fakultas Kehutanan UNILAK.

\section{Bentuk Arsitektur Pohon Arboretum}

\section{Model Aubreville}

Model Aubreville merupakan model arsitektur pohon dengan ciri batang monopodial dengan percabangan yang tumbuh ritmik, sehingga mengakibatkan cabang plagoitropik tersusun dalam lapisan terpisah. Jenis-jenis pohon dengan model arsitektur Aubreville yang terdapat di Arboretum UNILAK disajikan pada Gambar 4.

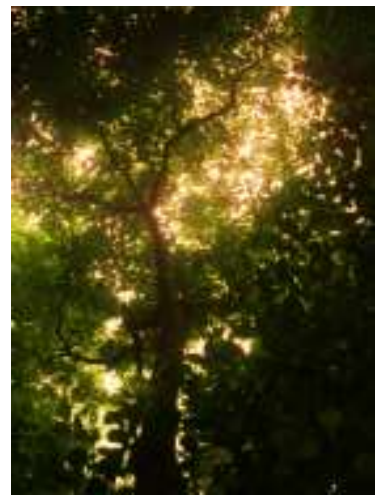

(a)

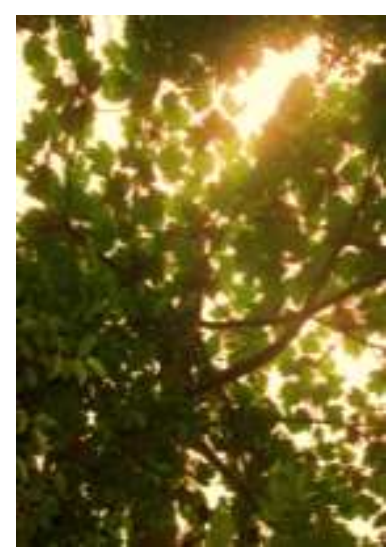

(c)

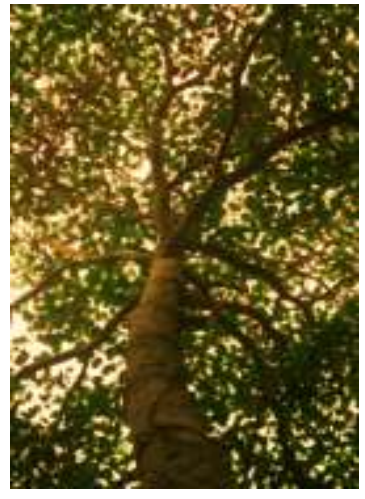

(b)

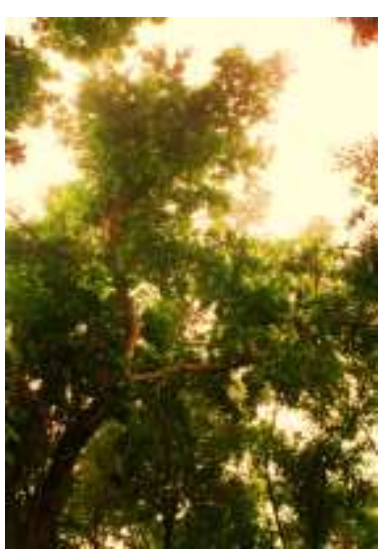

(d)
Gambar 4. Model Aubreville : (a) Bangkinang; (b) Sendok sendok; (c) Mahang; (d) Balam.

Jenis jenis pohon seperti pada Gambar 4 menunjukkan bahwa model aristektur ini memungkinkan banyak terjadi air lolos tajuk dan sedikit aliran batang. Hal ini akan berpengaruh pada besarnya aliran permukaan, infiltrasi dan erosi. Apabila lantai hutan bersih (sedikit serasah) akan menimbulkan potensi aliran permukaan yang cukup besar, tetapi jika serasah cukup maka potensi infiltrasi cukup besar. Jenis pohon ini dengan model arsitekturnya 
juga memiliki potensi intersepsi yang tinggi. Bagi satwa liar khususnya burung dan mamalia jenis-jenis pohon ini dapat dijadikan sebagai tempat istirahat yang cukup nyaman karena ranting cenderung datar.

\section{Model Champagnat}

Model Champagnat merupakan model yang memiliki ciri batang berupa simpodial, setiap koulomner melengkung karena terlalu berat dan tidak mendukung oleh jaringan penyokong yang cukup. Filotaksis spiral terdapat pada sumbu yang tidak banyak berbeda morfologi ujung dan pangkalnya. Pohon yang termasuk model ini di Arboretum UNILAK antara lain Tawota (Pleomele lincarifolia) seperti pada Gambar 5.

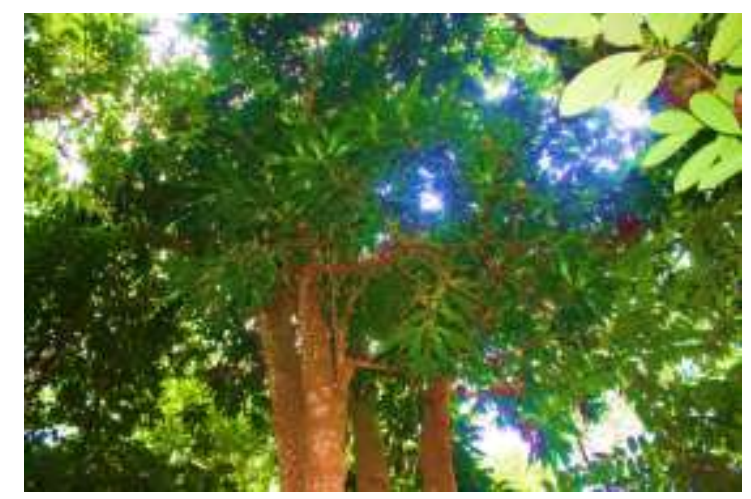

Gambar 5. Model Champagnat :

Tawota (Pleomele

lincarifolia).
Jenis pohon ini seperti pada Gambar 5 di atas memiliki potensi air lolos tajuk yang cukup besar dan aliran batang yang kecil karena secara umum ranting-rantingnya mengarah ke bawah. Hal ini akan berpengaruh pada besarnya aliran permukaan, infiltrasi dan erosi. Apabila lantai hutan bersih (sedikit serasah) akan menimbulkan potensi aliran permukaan dan erosi yang cukup besar, tetapi jika serasah cukup maka potensi infiltrasi cukup besar dalam waktu tertentu. Jenis pohon ini dengan model arsitekturnya juga memiliki potensi intersepsi yang kecil. Bagi satwa liar khususnya burung dan mamalia jenis-jenis pohon ini kurang nyaman sebagai tempat istirahat karena ranting cenderung mengarah ke bawah.

\section{Model Koriba}

Model Koriba merupakan model arsitektur pohon yang memiliki ciri batang simpodial dengan beberapa bagian batang tumbuh secara plagiotropik kecuali satu diantaranya tumbuh ortotropik. Cabang pertama letaknya bertentangan dengan cabang kedua/zig-zag Kuncup terminal terhenti karena jaringan meristem apeks berdiferensiasi menjadi parenkim. Kuncup aksilar yang berkembang dekat 
di bawahnya, membentuk koulomner yang semula identik namun terjadi perbedaan. Satu menjadi koulomner batang dan yang lain menjadi koulomner cabang. Contoh pohon yang termasuk model ini di Arboretum UNILAK antara lain Matoa (Pometia pinnata) seperti pada Gambar 6.

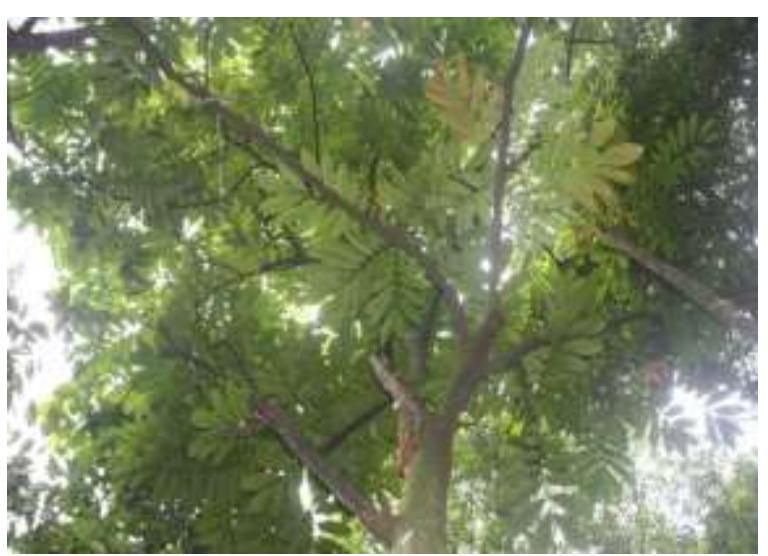

Gambar 6. Model Koriba : Matoa

(Pometia pinnata).

Jenis jenis pohon seperti pada Gambar 6 menunjukkan bahwa model aristektur ini memungkinkan banyak terjadi aliran batang dan air lolos tajuk sedikit. Hal ini akan berpengaruh pada besarnya aliran permukaan, infiltrasi dan erosi. Apabila lantai hutan bersih (sedikit serasah) akan menimbulkan potensi aliran permukaan yang cukup besar dan infiltarsi kecil, tetapi jika serasah cukup maka potensi infiltrasi cukup besra untuk waktu tertentu. Jenis pohon ini dengan model arsitekturnya juga memiliki potensi intersepsi yang tinggi. Bagi satwa liar khususnya burung dan mamalia jenis-jenis pohon ini dapat dijadikan sebagai tempat bersarang dan mempertahankan diri yang cukup nyaman karena tajuk lebar serta ranting cenderung rapat.

\section{Model Leeuwenberg}

Model Leeuwenberg merupakan model arsitektur yang memiliki ciri batang berupa simpodial, namun setiap koulomner menghasilkan lebih dari satu koulomner anak di ujungnya yang menempati ruang yang ada. Contoh pohon dengan model arsitektur Leeuwenberg. yang terdapat di Arboretum UNILAK adalah Bintangur (Calophyllum inophyllum) seperti pada Gambar 7.

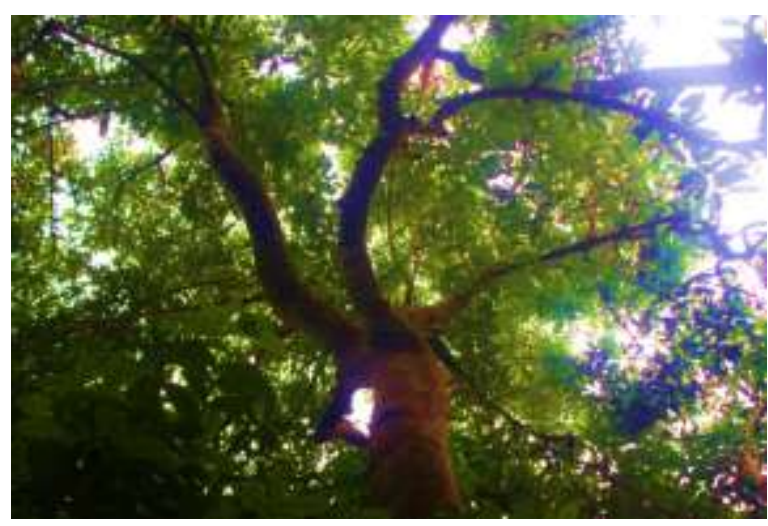

Gambar 7. Model Leeuwenberg :

Bintangur (Calophyllum inophyllum).

Jenis jenis pohon seperti pada Gambar 7 menunjukkan bahwa model aristektur ini memungkinkan banyak 
terjadi aliran batang dan air lolos tajuk sedikit. Hal ini akan berpengaruh pada besarnya aliran permukaan, infiltrasi, erosi dan intersepsi. Apabila lantai hutan bersih (sedikit serasah) akan menimbulkan potensi aliran permukaan yang cukup besar dan infiltarsi kecil, tetapi jika serasah cukup maka potensi infiltrasi cukup besar untuk waktu tertentu. Jenis pohon ini dengan model arsitekturnya juga memiliki potensi intersepsi yang cukup tinggi. Bagi satwa liar khususnya burung dan mamalia jenis pohon ini dapat dijadikan sebagai tempat bersarang dan mempertahankan diri yang cukup nyaman karena ranting cenderung rapat mengarah ke atas.

\section{Model Massart}

Model Massart merupakan model percabangan batang yang memiliki ciri batang monopodial ortotropik, pertumbuhan ritmik mengakibatkan cabang tersusun dalam karangan. Filotaksis pada batang adalah spiral. Cabang bersifat plagiotropik dengan filotaksis distrik atau cenderung distrik. Cabang dapat bersifat simpodial atau monopodial. Contoh pohon dengan model arsitektur ini. yang terdapat di Arboretum UNILAK adalah Mendarahan
(Horsfielda grandis) seperti pada Gambar 8.

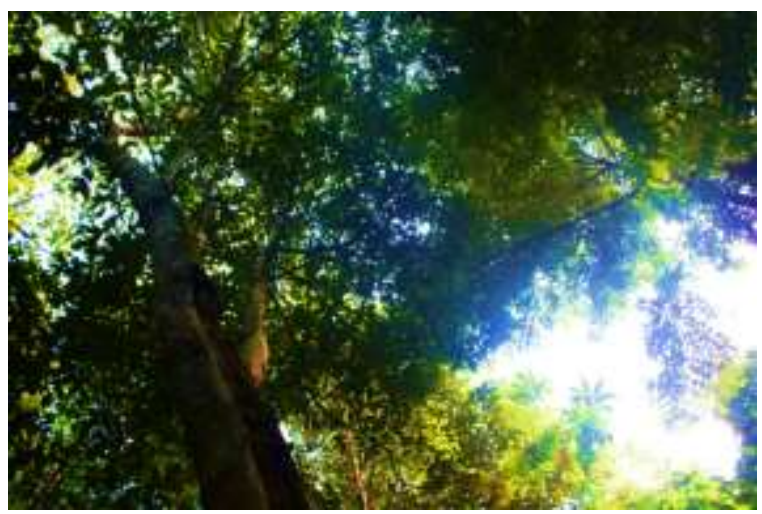

Gambar 8. Model Massart : Mendarahan (Horsfielda grandis).

Jenis pohon seperti pada Gambar 8 menunjukkan bahwa model aristektur ini memungkinkan banyak terjadi air lolos tajuk dan sedikit aliran batang. Hal ini akan berpengaruh pada besarnya aliran permukaan, infiltrasi, erosi dan intersepsi. Apabila lantai hutan bersih (sedikit serasah) akan menimbulkan potensi aliran permukaan yang cukup besar dan infilrasi kecil, tetapi jika serasah cukup maka potensi infiltrasi cukup besar untuk waktu tertentu. Jenis pohon ini dengan model arsitekturnya juga memiliki potensi intersepsi lebih kecil dari model Aubreville. Bagi satwa liar khususnya burung dan mamalia jenis pohon ini dapat dijadikan sebagai tempat istirahat yang cukup nyaman karena ranting cenderung datar. 


\section{Model Prevost}

Model Prevost merupakan model arsitektur yang memiliki ciri Batang simpodial dan ortotropik. Terdapat batang yang tumbuh proleptik di bagian bawah percabangan batang utama. Cabang simpodial dan plagiotropik. Contoh pohon dengan model arsitektur ini. yang terdapat di Arboretum UNILAK adalah Pulai (Alstonia scholaris) dan Pasir pasir (Stemonurus scorpiodes) seperti pada Gambar 9.

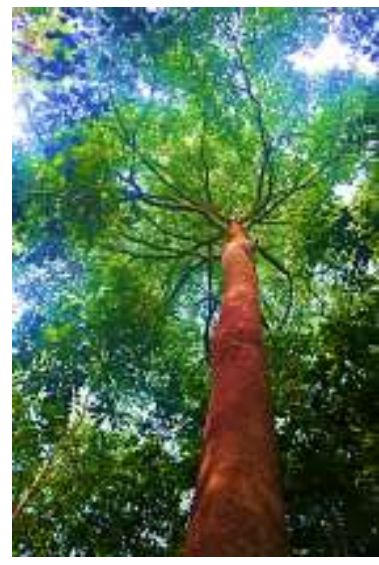

(a)

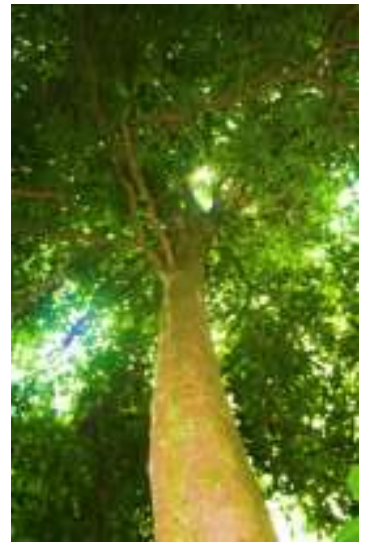

(b)
Gambar 9. Model Prevost : (a) Pulai (Alstonia scholaris) dan (b) Pasir pasir (Stemonurus scorpiodes).

Jenis jenis pohon seperti pada Gambar 9 menunjukkan bahwa model aristektur ini memungkinkan banyak terjadi air lolos tajuk dan sedikit aliran batang. Hal ini akan berpengaruh pada besarnya aliran permukaan, infiltrasi dan erosi. Apabila lantai hutan bersih (sedikit serasah) akan menimbulkan potensi aliran permukaan yang cukup besar, tetapi jika serasah cukup maka potensi infiltrasi cukup besar. Jenis pohon ini dengan model arsitekturnya juga memiliki potensi intersepsi yang tinggi. Bagi satwa liar khususnya burung dan mamalia jenis-jenis pohon ini dapat dijadikan sebagai tempat istirahat yang cukup nyaman karena ranting cenderung datar.

\section{Model Rauh}

Model rauh merupakan model arsitektur pohon yang memiliki ciri batang monopodial ortotropik. Pertumbuhan ritmik mengakibatkan cabang tersusun dalam karangan, cabang juga bersifat ortotrop sumbu dapat tumbuh tidak terbatas. Percabangan secara morphogenetic ekuivalen dengan batang. Percabangan ini tumbuh secara orthotropic dan definite. Setiap cabang mempunyai daun yang tersusun secara spiral. Contoh pohon dengan model arsitektur ini. yang terdapat di Arboretum UNILAK adalah Rengas, Lalan, Karet, Terap, Tempunik, Trempinis, Teampinai, Tenggayun, Beringin dan Kemenyan seperti pada Gambar 10. 


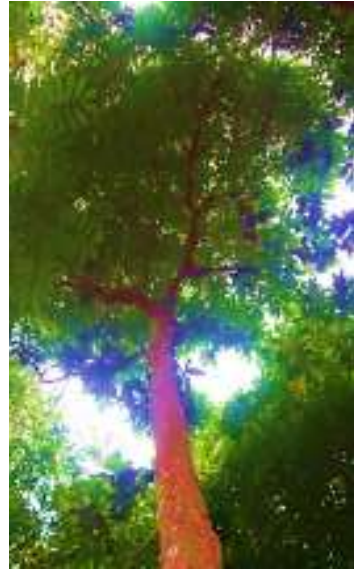

(a)

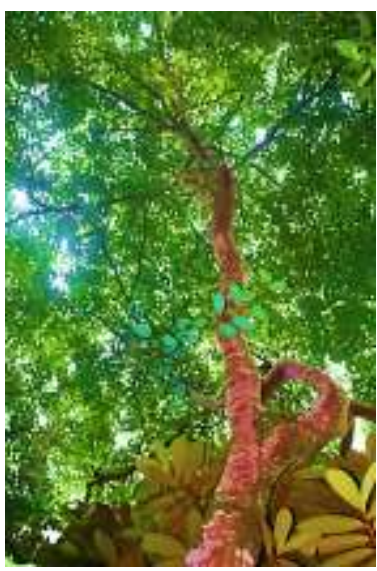

(c)

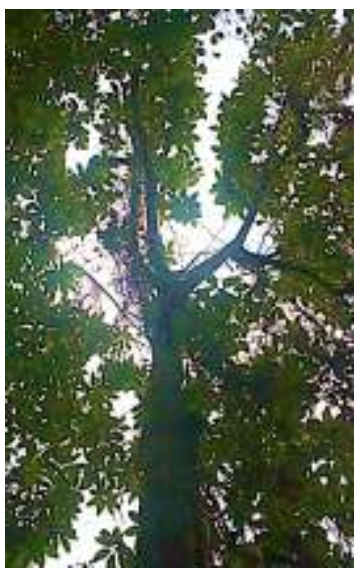

(b)

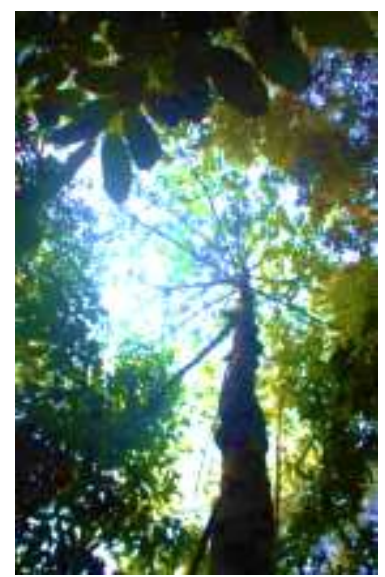

(d)
Gambar 10. Model Rauh : (a) Renghas (Gluta renghas); (b) Terap (Artocarpus elasticus); (c) Beringin (Ficus benjamina); (d) Kemenyan benzoin).

(Styrax

Jenis jenis pohon seperti pada Gambar 10 menunjukkan bahwa model aristektur ini memungkinkan banyak terjadi aliran batang dan air lolos tajuk sedikit. Hal ini akan berpengaruh pada besarnya aliran permukaan, infiltrasi dan erosi. Apabila lantai hutan bersih (sedikit serasah) akan menimbulkan potensi aliran permukaan yang cukup besar dan infiltarsi kecil, tetapi jika serasah cukup maka potensi infiltrasi cukup besar untuk waktu tertentu. Jenis pohon ini dengan model arsitekturnya juga memiliki potensi intersepsi yang tinggi. Bagi satwa liar khususnya burung dan mamalia jenis-jenis pohon ini dapat dijadikan sebagai tempat bersarang dan mempertahankan diri yang cukup nyaman karena tajuk lebar serta ranting cenderung rapat.

\section{Model Roux}

Model Raux merupakan model arsitektur yang memiliki ciri batang monopodial ortotropik dan simpodial namun lebih sering monopodial. Cabang kontinu atau tersebar dan filotaksis batang adalah spiral. Berbeda dengan model Massart, pada model Roux cabang-cabang pohon tidak ritmik, tetapi menerus pada batang. Contoh pohon dengan model arsitektur ini. yang terdapat di Arboretum UNILAK adalah Jangkang, Mempisang, Meranti, Meranti Daun Besar, Meranti Rawa dan Gaharu seperti pada Gambar 11. 


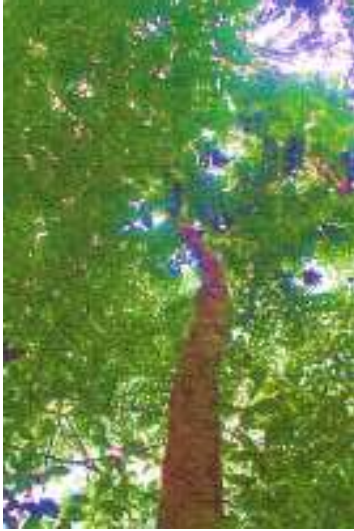

(a)

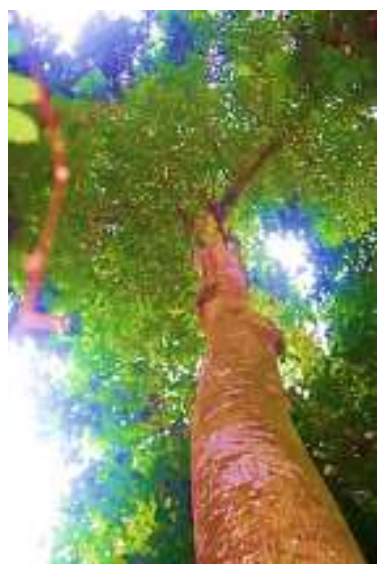

(c)

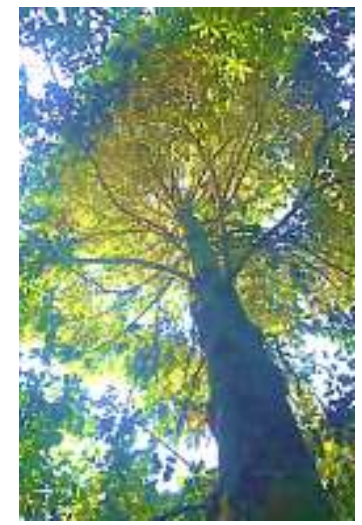

(b)

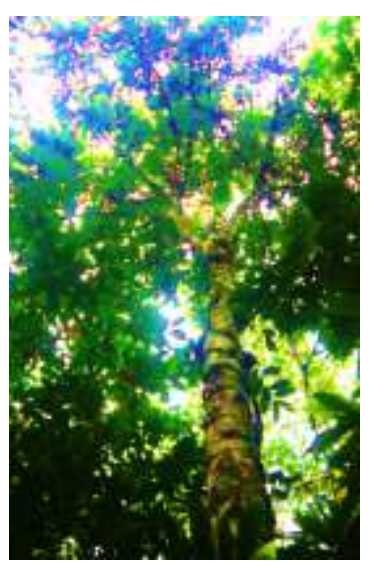

(d)
Gambar 11. Model Roux : (a) Jangkang ferruginga); Balangeran balangeran); (c) Gaharu (Aquilaria malaccensis); (d) Mempisang (Polyalthia hypoleuca).

Jenis jenis pohon seperti pada Gambar 11 menunjukkan bahwa model aristektur ini memungkinkan banyak terjadi air lolos tajuk dan aliran batang sedikit. Hal ini akan berpengaruh pada besarnya aliran permukaan, infiltrasi dan erosi. Apabila lantai hutan bersih (sedikit serasah) akan menimbulkan

potensi aliran permukaan yang cukup besar dan infiltarsi kecil, tetapi jika serasah cukup maka potensi infiltrasi cukup besar untuk waktu tertentu. Jenis-jenis pohon ini dengan model arsitekturnya juga memiliki potensi intersepsi yang tinggi tetapi lebih kecil dari model Rauh. Bagi satwa liar khususnya burung dan mamalia jenisjenis pohon ini dapat dijadikan sebagai tempat bersarang dan beristirahat yang cukup nyaman karena tajuk lebar serta ranting cenderung rapat dan mendatar.

\section{Model Scarrone}

Model Scarrone merupakan model arsitektur yang memiliki ciri batang monopodial, percabangan ritmik. Cabang simpodial dan ortotropik. Contoh pohon dengan model arsitektur ini. yang terdapat di Arboretum UNILAK adalah Terentang, Simpur, Keranji dan Rambutan hutan seperti pada Gambar 12.

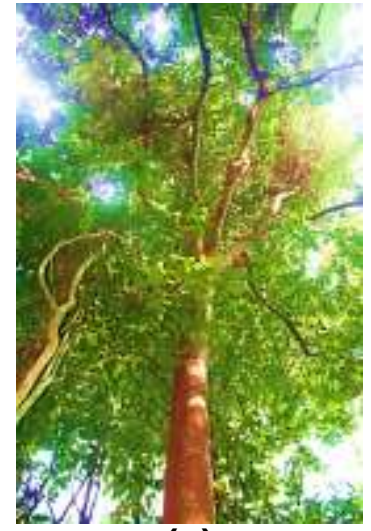

(a)

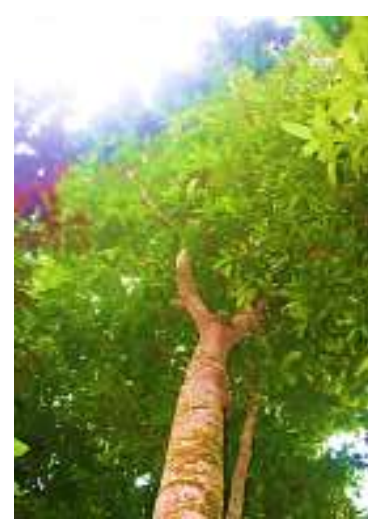

(b) 


\section{Gambar 12. Model Scarrone : (a) Simpur (Dillenia grandifolia); (b) Keranji (Dialium indum).}

Jenis jenis pohon seperti pada Gambar 12 menunjukkan bahwa model aristektur ini memungkinkan banyak terjadi aliran batang dan air lolos tajuk sedikit. Hal ini akan berpengaruh pada besarnya aliran permukaan, infiltrasi, erosi dan intersepsi. Apabila lantai hutan bersih (sedikit serasah) akan menimbulkan potensi aliran permukaan yang cukup besar dan infiltarsi kecil, tetapi jika serasah cukup maka potensi infiltrasi cukup besar untuk waktu tertentu. Jenis pohon ini dengan model arsitekturnya juga memiliki potensi intersepsi yang cukup tinggi. Bagi satwa liar khususnya burung dan mamalia jenis pohon ini dapat dijadikan sebagai tempat bersarang dan mempertahankan diri yang cukup nyaman karena ranting cenderung rapat dan berlapis serta mengarah ke atas.

\section{Model Troll}

Model Troll merupakan model arsitektur pohon dengan ciri batang simpodial. Semua sumbu berarah plagiotropik sejak dini. Pohon berbunga setelah dewasa, daun cenderung berhadapan. Sumbu pertama bersifat

ortotropik, sumbu berikutnya mulai berdiferensiasi ke arah horizontal secara bertahap. Pembentukkan batang yang tegak terjadi setelah daun gugur. Contoh pohon dengan model arsitektur ini. yang terdapat di Arboretum UNILAK adalah Jengko,I Kandis, Balok, Sengon, Kacang pedang, Pagar-pagar, Nangka hutan, Jambu-jambu, Pelawan putih, Petatal dan Laban seperti pada Gambar

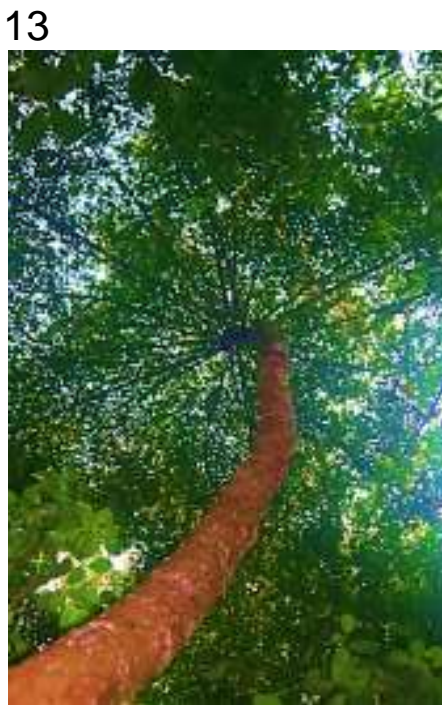

(a)

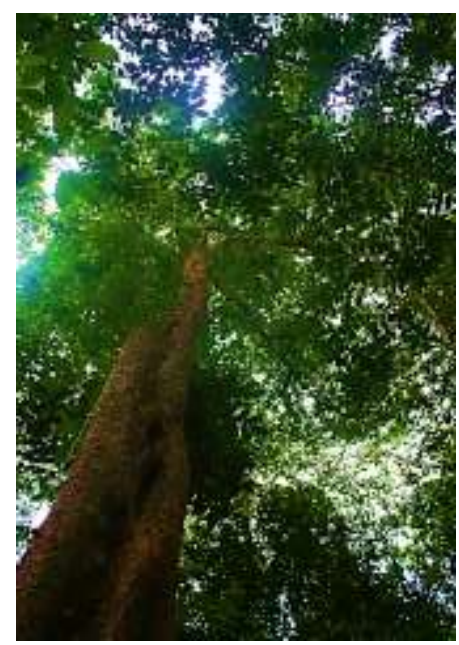

(c)

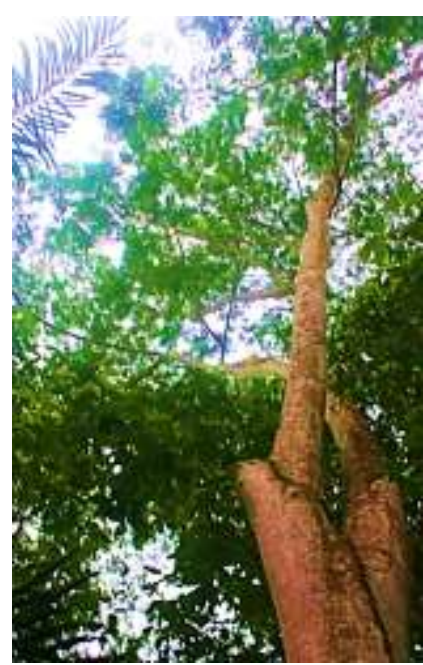

(b)

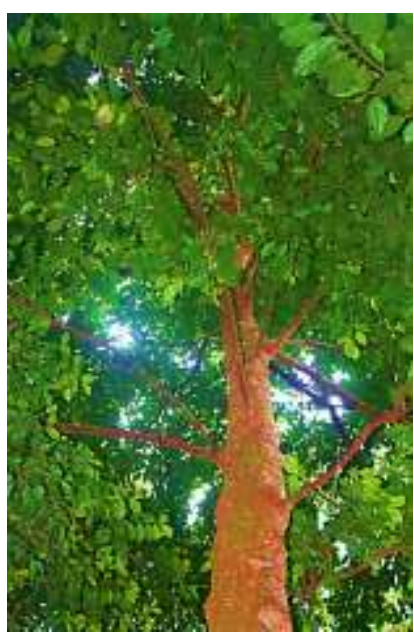

(d) 
Gambar 13. Model Troll : (a) Kandis (Garcinia parvifolia); (b)

Sengon

(Falcataria

moluccana); (c) Pagar

Pagar (Ixonanthes reticulate); (d) Petatal (Ochanostachys amentacea).

Jenis pohon seperti pada Gambar 13 menunjukkan bahwa model aristektur ini memungkinkan banyak terjadi air lolos tajuk dan sedikit aliran batang. Hal ini akan berpengaruh pada besarnya aliran permukaan, infiltrasi, erosi dan intersepsi. Apabila lantai hutan bersih (sedikit serasah) akan menimbulkan potensi aliran permukaan yang cukup besar dan infilrasi kecil, tetapi jika serasah cukup maka potensi infiltrasi cukup besar untuk waktu tertentu. Jenis pohon ini dengan model arsitekturnya juga memiliki potensi intersepsi lebih kecil dari model Aubreville. Bagi satwa liar khususnya burung dan mamalia jenis pohon ini dapat dijadikan sebagai tempat istirahat yang cukup nyaman karena ranting cenderung datar.

\section{Pemanfaatan Model Arsitektur Pohon} dalam Menunjang Pembelajaran

Keragaman pola percabangan batang pada bentuk/model arsitektur di Arboretum UNILAK cukup tinggi, hal ini ditunjukkan pada lokasi penelitian ditemukan 10 bentuk/model pola percabangan batang pohon yang berhasil diidentifikasi. Hal tersebut menunjukkan bahwa pola percabangan batang pohon di Arboretum UNILAK cukup merata pada setiap jenis-jenis pohon yang ditemukan di lokasi penelitian.

Informasi pola percabangan yang mengarah pada arsitektur pohon juga menjadi dasar dalam pengembangan terapan pada pengembangan pembelajaran di kampus UNILAK. Pada pengembangan pembelajaran, informasi pola percabangan batang pohon bermanfaat sebagai dasar pertimbangan kegiatan praktikum. Penerapan pola percabangan batang/model arsitektur dalam pengembangan penunjang praktikum yaitu terkait dengan fungsi pohon dalam mentransformasi air hujan menjadi aliran batang, air lolos, aliran permukaan, infiltrasi dan erosi.

Hasil penelitian ini memberikan indikasi bahwa pola arsitektur percabangan batang pohon memiliki prospek yang baik sebagai topik penelitian karena keragaman informasi di Arboretum UNILAK cukup tersedia. Selain itu, hasil penelitian seperti ini 
akan memberikan sumbangsih kepada konsep pengembangan proses pembelajaran. Hasil penelitian ini dapat digunakan oleh mahasiswa dalam praktikum Hidrologi Hutan, Pengelolaan Daerah Aliran Sungai, IImu Hutan Kota, Dendrologi, Konservasi Tanah dan Air dan Klimatologi Hutan.

Praktikum merupakan salah satu kegiatan belajar mahasiswa yang dapat berlangsung di dalam ruang maupun di luar ruang (laboratorium terbuka). Praktikum di laboratorium terbuka bertujuan untuk memberikan motivasi bagi mahasiswa untuk melatih daya ingat, pengetahuan dan keterampilannya. Sehingga mahasiswa tidak hanya menerima apa yang ada dalam teori, namun dapat dibuktikannya di laboratorium terbuka tersebut. Manfaat model praktikum ini dapat dijadikan sebagai sarana komunikasi yang digunakan dalam pengembangan pada praktikum beberapa matakuliah di Fakultas Kehutanan UNILAK.

\section{KESIMPULAN DAN SARAN}

\section{Kesimpulan}

Berdasarkan hasil penelitian yang telah dilakukan, dapat ditarik kesimpulan sebagai berikut: didapatkan 10 bentuk/model arsitektur pohon dari
41 jenis pohon (diamater $\geq 20 \mathrm{~cm}$ ). Bentuk/model arsitektur pohon di Arboretum yaitu Aubreville, Champagnat, Koriba, Leeuwenberg, Massart, Prevost, Rauh, Roux, Scarrone dan Troll. Hasil penelitian seperti ini akan memberikan sumbangsih kepada konsep pengembangan proses pembelajaran. Hasil penelitian ini dapat digunakan oleh mahasiswa dalam praktikum Hidrologi Hutan, Pengelolaan Daerah Aliran Sungai, IImu Hutan Kota, Dendrologi dan Klimatologi

\section{Saran}

Agar hasil penelitian ini dapat dipertimbangkan oleh pihak pimpinan fakultas dalam rangka peningkatan pengembangan proses pembelajaran untuk berbagai mata kuliah.

\section{DAFTAR PUSTAKA}

Alif, A, 2000. Pengaruh Arsitektur Pohon Model Massartd dan Rauh Terhadap Aliran Batang, Curah Tajuk, Aliran Permukaan dan Erosi di Hutan Pendidikan Gunung Walat Sukabumi, Bogor ; IPB.

Arrijani, 2006. Model arsitektur pohon pada Hulu DAS Cianjur Zona Sub-Montana Taman Nasional gunung Gede Pangrango, Disertasi. Bogor: Institut Pertanian Bogor. 
Arsyad S. 2006. Konservasi Tanah dan Air. Bogor: IPB Press.

Halle, F. dan R.A.A. Oldeman. 1975. An Essay on the Architecture and Dynamics of Growth of Tropical Trees. Penerbit University Malaya, Kuala Lumpur Malaysia.

Hidayat, E. B, Morfologi Tumbuhan Bandung ; jurusan Biologi ITB , 1992.

Marina,S.U. 2011. Korelasi Arsitektur Pohon Terhadap Konservasi Tanah dan air di Area PHBM Gambung KPH Bandung Selatan, Bogor; IPB.

Oldeman, LR, 1994. The Global Extent of Soil Degradation. In: Soil Resilience and Sustainable Land Use, Greenland, D.J. and I. Szabolcs (Eds.). CAB International, Wallingford, UK., pp: 99-118.

Tjitrosoepomo,G. 2007. Morfologi Tumbuhan, Yogyakarta: Gadjah Mada University Press. 